\title{
MANUFACTURE AND PERFORMANCE EVALUATION OF A LOCAL UNIT FOR PRODUCING COMPOST TEA
}

\author{
M. M. Badr*
}

\section{ABSTRACT}

Experiments were carried out to manufacture and evaluate the performance of a local unit for producing compost tea. The performance of the manufactured unit was studied as a function of change in material dilution percentage, temperature degree, air pressure and fermentation period. Performance evaluation of the manufactured unit was carried out in terms of extraction efficiency, unit productivity, required power, specific energy and operational cost.

The experimental results reveal that that the highest values of unit productivity and extraction efficiency were (1.64 $\mathrm{l} / \mathrm{h}$ and $95.33 \%)$, while the lowest values of specific energy and operational cost were $(0.26 \mathrm{kw} . \mathrm{h} / \mathrm{l}$ and 2.29 L.E./l) respectively under the following conditions:

- The use of the manufactured unit for producing compost tea.

- Operate the manufactured unit at a temperature degree of about $25^{\circ} \mathrm{C}$.

- Adjust the air pressure at $1.5 \mathrm{~kg} / \mathrm{cm}^{2}$.

- Operate the manufactured unit at a fermentation period of about $24 \mathrm{~h}$.

- Adjust the dilution percentage at about 1:10.

\section{INTRODUCTION}

gricultural policy depends on the successful technology through
mechanizing the agricultural processes. Field crop residues are
considered one of the most critical problems which face the Egyptian farmers. Accumulation of these residues in large quantities results not only in deterioration of the environment but also in a loss of potentially valuable material. Manuring with these residues through composting is a promising route, especially with the increase in fertilizer price. Composting is the biological reduction of organic wastes to humus. The good composting structure depends on the correct mixing and aeration of materials. Compost tea is a liquid extract of compost obtained by mixing compost and water for a defined period of time.

\section{"Lecturer of Agric. Eng., Fac. of Agric., Zagazig Univ. Egypt.}


Compost tea contains nutrients and a range of different organisms and is applied to the soil or directly to plants with the principal aim of suppressing certain plant diseases. Compost tea can be used to restore beneficial microbes to soil and plants. The benefits of these microbes include protecting plants, improving nutrient uptake, retaining nutrients in the soil, improving soil tillage, increasing root depth and improving all aspects of the soil. The benefit of tea compost is its ability to start with good compost that contains aerobic beneficial microbes and growing and multiplying them. Ingham (2003) stated that compost tea contains soluble nutrients that perform two key functions: they feed the organisms already within the tea, so they grow faster, are healthier, and can perform their disease suppressive functions faster; they feed the plant, making it healthier and able to make more food to feed the "good guys" that suppress disease-causing organisms. In addition to suppressing disease, the organisms in tea confer other crucial benefits on plants: they retain nutrients in the soil around the plants, so additional fertilizer will not be needed; they make nutrients available to plants at the rates plants require; they detoxify the soil and water, making it easier for plants to grow; and they build soil structure, so air and water can easily reach plant's roots. He also fabricated a small tea maker using a twenty-liter bucket, two aquarium air pumps, and four air stones. He added that the machine makes tea in 24 to 48 hours. Biodynamic systems and horse trough machines take longer because they go through an anaerobic phase and return to aerobic after enough time has passed. Scheuerell (2003) mentioned that compost tea is compost extract that is brewed with a microbial food source (such as molasses, kelp, rock dust, humic-fulvic acids and others). The compost tea brewing technique (aerobic or anaerobic) extracts and grows populations of beneficial microorganisms. Scheuerell and Mahaffee (2004) stated that compost tea is being used increasingly in agricultural production to control plant diseases. However, there have been limited studies relating disease control efficacy to various compost tea production methods, particularly compost tea produced with active aeration and additives to increase microbial population densities in compost tea. Aerated compost tea (ACT) and non- 
aerated compost tea (NCT), produced with or without additives, was studied for the suppression of damping-off of cucumber. The effect on damping-off ranged from not suppressive to consistently suppressive depending on the method used to produce the tea. The most consistent formulation for damping-off suppression was ACT produced with kelp and humic acid additives. Producing ACT with a molasses-based additive inconsistently suppressed damping-off. Residual nutrients can interfere with disease suppression. Heating or diluting the compost tea negated suppression. Ingham (2005) explained the Bucket-Bubbler technique allows small quantities of compost tea to be made inexpensively. For this method, a 15 to $20 \mathrm{~L}$ bucket is fitted with air bubblers that are attached to an aquarium type aeration pump. The bucket is half filled with water and air is passed through it for approximately 10-20 minutes from the air bubblers. Compost is then added to fill the bucket to within $2 \mathrm{~cm}$ from the top (to allow for bubbling). The aerator provides a continuous flow of air and creates enough turbulence to mix the brew. The minimum time for brewing is 2-3 days. To harvest the brew, the aerator is turned off for half an hour or so to allow most of the solids settle to the bottom of the bucket. The soluble portion of the tea is decanted from the top, leaving the insoluble solids, which can be returned to the compost pile. Scheuerell and Mahaffee (2006) referred to numerous compost tea production parameters (compost source, aeration, nutrient additives, production duration, and use of application adjutants) were tested for suppressing gray mold on geranium. For non-aerated compost tea (NCT), the most consistent, significant disease suppression was associated with particular compost samples and increased production time, with little effect of periodic stirring or the addition of nutrients at the onset of production. Continuously aerating compost tea did not significantly increase disease suppression compared with nonaerated compost teas. Preparing aerated compost tea (ACT) with nutrient additives did not consistently increase disease suppression; however, $67 \%$ of ACT batches made with a mixture of kelp extract, rock dust, and humic acid significantly reduced disease. Carballo et al. (2008) produced 12 compost extracts under varying conditions in a purpose-built reactor. Two different composts, an stable 
compost produced from manure and an unstable compost produced from municipal solid waste, respectively, two aeration systems (aerated and nonaerated extracts) and three temperatures (10, 20 and 30 degrees $C)$ were used in these experiments. Extracts produced from high stability compost, independently of the conditions of aeration and temperature, showed very similar results. In contrast, differences among extracts produced from the unstable compost were more noticeable. However, the different conditions of aeration and temperature during the production of the extracts only explained partially these differences, since the transformations undergone by compost over the 3 months that the experiments lasted were also reflected in the composition of the extracts. Degradation was more intense for nonaerated processes, probably due to the longer duration of these (10 days) with respect to aerated extractions (2 days). High temperatures could increase micro organism activity and consequently favor the degradation of easily oxidizable organic matter. Carballo et al. (2009) carried out 24 assays on compost tea produced from three different composts: one produced from bovine manure (M) and two others made from municipal solid waste but differing in the degree of stability (stable: MSW I and unstable: MSW II); using two aeration systems: continuous and discontinuous aeration, and at three temperatures: 10, 20 and 30 degrees $\mathrm{C}$. In addition, the evolution of phytotoxicity over the period of extraction was also studied, as well as the influence that dilution of the tea before its application has on phytotoxicity. They found that aeration and temperature influenced compost tea phytotoxicity, with aerated teas produced at low temperatures causing less phytotoxicity. Furthermore, tea phytotoxicity was also dependent on the stability of the compost from which the tea was produced; unstable compost produced compost teas of greater phytotoxicity. Palmer et al. (2010) produced and characterized an aerated compost tea (ACT) that suppressed growth of the plant pathogen. Three different openwindrow composts were sampled weekly from the early secondary mesophilic stage until maturity. Each $10 \mathrm{~kg}$ of compost sample was extracted in 301 of aerated water for 24,48 or $72 \mathrm{~h}$. Relative to water, all batches of ACT applied to detached bean leaflets reduced lesion development. There was a significant linear, inverse relationship between 
the internal windrow temperature of compost $\leq 51$ degrees $\mathrm{C}$ used to prepare ACT and the extent of lesion development. The compost weight-to-water volume ratios of 1:3, 1:10 or 1:30, using compost sampled from a fourth windrow at 50 degrees $\mathrm{C}$, also produced ACTs that reduced the lesion development. So, such care had to be taken to design, manufacture and develop a simple low cost unit from local material to be used for producing compost tea taking into consideration its effectiveness. There are numerous variations in compost tea producing equipment. These range from homedesigned pieces to commercially available equipment, and every year efforts to improve efficiency and decrease costs result in different designs and new tea making processes being introduced and variously tested.

There are many factors that control the performance of compost extraction unit. These factors include dilution percentage, temperature degree, air pressure, fermentation period and additives. The mentioned factors affect directly on the extraction efficiency, unit productivity, required power, energy requirements and the total operational cost.

So, the objectives of this study are to:

- Manufacture of a local unit for producing compost tea from low cost local materials to improving aspects of the soil.

- Optimize some operating parameters (dilution percentage, temperature degree, air pressure, and fermentation period) affecting the performance of the manufactured unit.

- Evaluate the manufactured unit from the economic point of view.

\section{MATERIALS AND METHOD}

Experiments were carried out through the year of 2012 at Department of Agricultural Engineering, Faculty of Agriculture, Zagazig University to evaluate the performance of a local manufactured unit for producing compost tea.

\subsection{MATERIALS:}

\subsubsection{The used compost:}

Crop residues (especially rice straw) were used as a raw material for producing compost. Poultry and live-stock manure were also used to accelerate composting process. Added to that finished compost was used as a supply of microorganisms. Crop residues were formed in piles. Piles were then mixed and turned four times per month for four months till maturity. 
After maturity, the obtained compost is ready for making compost tea. The main specifications of the used Compost are illustrated in Table (1).

Table (1): some properties of the used compost

\begin{tabular}{|c|c|c|c|c|c|c|}
\hline $\begin{array}{c}\text { Nitrogen, } \\
\%\end{array}$ & $\begin{array}{c}\text { Phosphor, } \\
\%\end{array}$ & $\begin{array}{c}\text { M.C., } \\
\%\end{array}$ & $\begin{array}{c}\text { Organic } \\
\text { matter, } \%\end{array}$ & $\begin{array}{c}\text { Organic } \\
\text { carbon, } \%\end{array}$ & $\mathrm{pH}$ & $\mathrm{EC}, \%$ \\
\hline 1.60 & 0.20 & 55 & 40 & 23 & 7.4 & 7.3 \\
\hline
\end{tabular}

\subsubsection{The manufactured unit for producing compost tea:}

A local unit for producing compost tea was manufactured from low cost, local material to overcome the problems of high power and high cost requirements under the use of the imported equipments. The unit was manufactured specially for this work and constructed at a private workshop in Sharkia Governorate. (Figs.1 and Photo 1) the manufactured unit consists mainly of aerobic digester, air compressor (pump), wood stand, air stones, strainer bag, plastic trunk and plastic T-valve. The other specifications of the manufactured unit are illustrated in Table (2).

Table (2): specifications of the manufactured unit

\begin{tabular}{|l|l||}
\hline Numbered of aerobic digesters & 4 aerobic digesters \\
\hline digester capacity & 50 liters \\
\hline Aeration & Fine Bubble Diffusion \\
\hline Air delivery & Linear diaphragm air pump \\
\hline Extent of volt & $110 \mathrm{~V} / 220 \mathrm{~V}$ \\
\hline Tank/Stand & UV stabilized polyethylene \\
\hline Valves & Plastic T-valves \\
\hline Unit mass & 100 kilos \\
\hline Unit dimensions & $200 * 40 * 30$ centimeters \\
\hline \hline
\end{tabular}

\subsubsection{The aerobic digester:}

The aerobic digester is a tank fabricated from plastic with a capacity of 50 litters and it is fixed on the wood stand. The digester is fitted with air bubblers that are attached to aeration pump.

\subsubsection{The air compressor (pump):}

The air compressor is used in the aerobic digester to make lots of bubbles air and provide oxygen in the digester. The compressor was powered by an electric motor $0.735 \mathrm{~kW}$ (1 hp). 


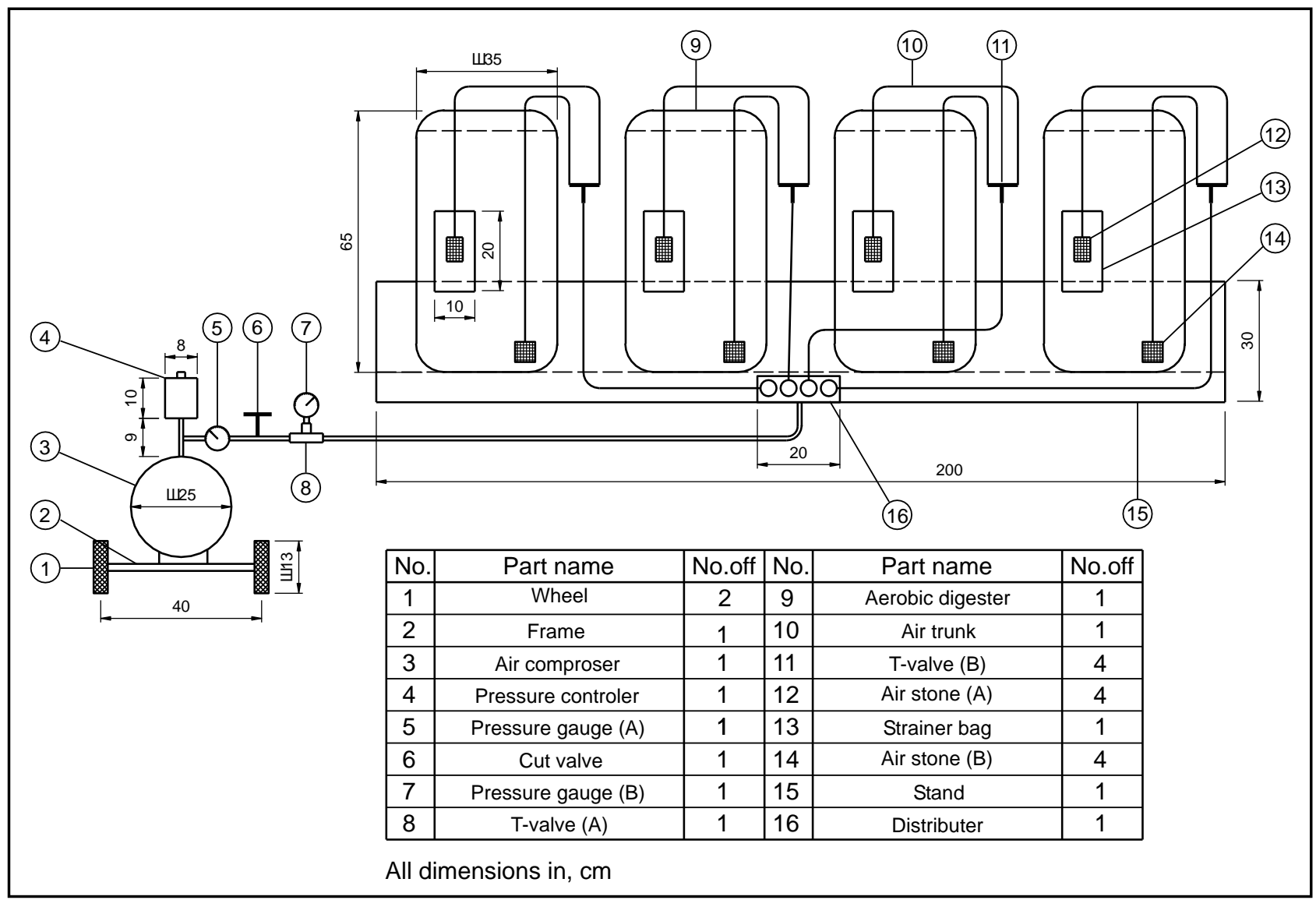

Fig. (1): Diagram of the compost tea production unit. 


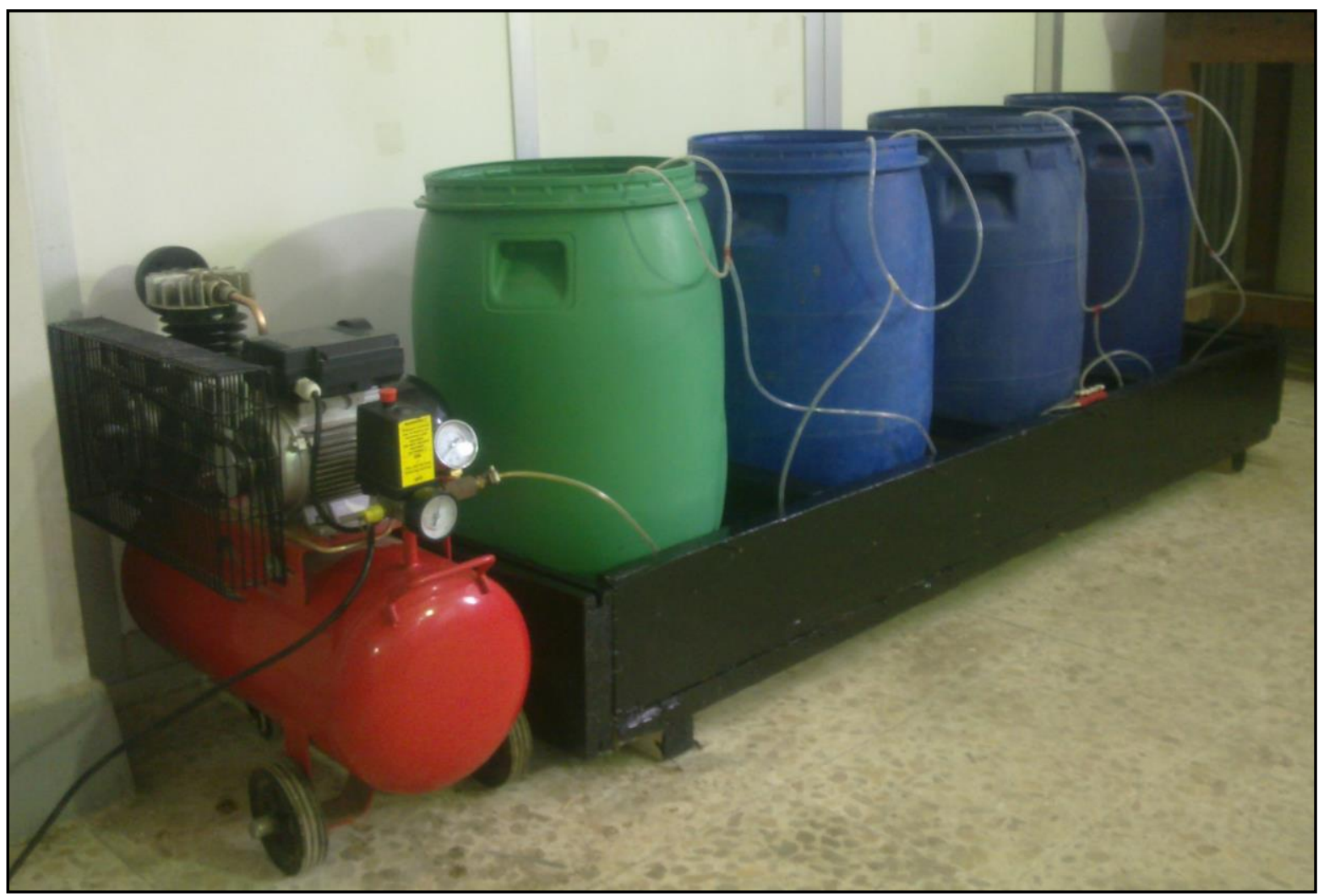

Photo (1): The compost tea production unit. 


\subsubsection{Wooden stand:}

The stand is made of rectangular wood Pillars. It includes elements to fix the aerobic digester, air compressor and the aeration system. It was carried by four ground wheels of $100 \mathrm{~mm}$ diameter.

\subsubsection{Air stones:}

Air stones are used in the aerobic digester to make lots of bubbles. These air stones are porous synthetic stones.

\subsubsection{T-valve and plastic trunks:}

T-valve is made of plastic. It is used to split the air line between the air stones. The air stones are connected to the air trunk.

\subsubsection{A strainer bag:}

It is a nylon bag used to hold compost inside the aerobic digester.

\subsection{METHOD:}

\subsubsection{Preparation method of compost tea:}

The aerobic digester was filled with water. The produced compost from crop residues was filled in the nylon bag and was put in the water inside the digester. Active additive (molasses $0.5 \%$ ) was added to increase microbial population densities in the compost tea. During the extraction period both mixing and aeration are important to the process of making compost tea. Mixing is an important part of the process, assisting the physical extraction of bacteria and fungi from the compost. Aeration was carried out by the compressor. The air compressor was supplied with two outlets. Air stones were connected to the air trunk. One air stone was put inside the compost bag and another one air stone was put at the bottom of the digester. The main point is that enough oxygen must always be present to prevent compost tea from going anaerobic (running out of Oxygen).

\subsubsection{Experimental design:}

The performance of the manufactured unit was experimentally measured under the following parameters:

- Four different dilution percentages, one part compost with 5, 10, 15 or 20 parts of water (1:5, 1:10, 1:15, and 1:20).

- Four different temperature degrees $\left(15,20,25\right.$, and $\left.30^{\circ} \mathrm{C}\right)$.

- Four different air pressures: $\left(0.5,1.0,1.5\right.$, and $\left.2.0 \mathrm{~kg} / \mathrm{cm}^{2}\right)$.

- Four different fermentation periods (12, 24, 36, and $48 \mathrm{~h}$ ).

\subsection{MEASUREMENTS AND DETERMINATIONS:}

Evaluation of the performance of the manufactured unit was based on the following indicators: 


\subsubsection{Unit productivity:}

Unit productivity was determined by the following equation:

$$
\mathrm{Up}=\frac{\mathrm{Ve}}{\mathrm{t}}, \quad \mathrm{l} / \mathrm{h}
$$

Where: $\mathrm{Up}=$ unit productivity, $1 / \mathrm{h}$

$\mathrm{Ve}=$ volume of extraction sample, 1

$t=$ the time consumed in the extraction operation, $h$

\subsubsection{Extraction efficiency:}

Extraction efficiency was calculated by using the following equation:

$$
\text { Extraction efficiency }(\%)=\frac{\mathrm{Ve}}{\mathrm{Vi}} \times 100
$$

Where: $\mathrm{Ve}=$ volume of extraction sample, 1

$\mathrm{Vi}=$ volume of input sample, 1

\subsubsection{Required power:}

The following formula was used to estimate the required power.

$$
\mathrm{P}=\sqrt{3} \times \cos \varphi \times \mathrm{I} \times \mathrm{V}
$$

Where: $\mathrm{P}=$ power required, $\mathrm{kW}, \quad \mathrm{I}=$ current intensity, Ampere

$$
\mathrm{V}=\text { Voltage },(220 \mathrm{v}) \quad, \cos \varphi=0.7
$$

\subsubsection{Specific energy:}

Specific energy for the extraction operation can be calculated as follows:

$$
\text { Specific energy }=\frac{\text { Compressorpower }}{\text { Unit productivity }}, \mathrm{kW} \cdot \mathrm{h} / \mathrm{l}
$$

\subsubsection{Operational cost:}

The operational cost required for the extraction operation was estimated using the following equation (Awady, 1982):

$$
\text { Operating cost }=\frac{\text { Hourly cost }}{\text { Machine productivity }}, \mathrm{L} \cdot \mathrm{E} / \mathrm{l}
$$

The hourly cost was determined by using the following equation (Awady, 1978):

$$
\mathrm{C}=\frac{\mathrm{p}}{\mathrm{h}}\left(\frac{1}{\mathrm{a}}+\frac{\mathrm{i}}{2}+\mathrm{t}+\mathrm{r}\right)+(\mathrm{W} . \mathrm{e})+\frac{\mathrm{m}}{144}
$$

Where:

$\mathrm{C}=$ machine cost, L.E./h

$\mathrm{h}=$ yearly working hours, $\mathrm{h} /$ year

$\mathrm{i}=$ interest rate/year $\mathrm{p}=$ price of machine, L.E.

$\mathrm{a}=$ life expectancy of the machine, $\mathrm{h}$

$\mathrm{t}=$ taxes, over heads ratio 
$\mathrm{r}=$ repairs and maintenance ratio

$\mathrm{W}=$ power of motor in $\mathrm{kW}$

$\mathrm{e}=$ hourly cost, L.E./kW.h

$\mathrm{m}=$ the monthly average wage, L.E.

$144=$ reasonable estimation of monthly working hours.

\section{RESULTS AND DISCUSSION}

The obtained results will be discussed under the following items:

\subsection{Influence of some operating parameters on unit productivity and extraction efficiency at different dilution percentages:}

Representative values of unit productivity and extraction efficiency versus temperature degree, air pressure and fermentation period at different dilution percentages are given in Fig.2. Concerning the effect of temperature degrees, results show that increasing temperature degree from 15 to $25^{\circ} \mathrm{C}$, measured at different dilution percentages of 1:5, 1:10, 1:15 and 1:20, increased unit productivity from 1.51 to 1.62 , from 1.55 to 1.64 , from 1.44 to 1.53 and from 1.39 to $1.49 \mathrm{l} / \mathrm{h}$, also increased extraction efficiency from 85.66 to 91.56 , from 90.36 to 95.33 , from 84.60 to 90.21 and from 82.32 to $88.10 \%$, respectively. Any further increase in temperature degree more than 25 up to $30^{\circ} \mathrm{C}$ measured at the same dilution percentages decreased unit productivity from 1.62 to 1.54 , from 1.64 to 1.58 , from 1.53 to 1.47 and from 1.49 to $1.44 \mathrm{l} / \mathrm{h}$, like this decreased extraction efficiency from 91.56 to 87.17, from 95.33 to 92.00 , from 90.21 to 86.24 and from 88.10 to $84.85 \%$, respectively at constant air pressure of $1.5 \mathrm{~kg} / \mathrm{cm}^{2}$ and fermentation period of $24 \mathrm{~h}$. Higher values of temperature degree more than the optimum value tend to decrease both of unit productivity and extraction efficiency because high temperature degrees increased the amount of compost loss that was delivered outside the digester with air. Lower values of temperature degree less than the optimum value tend to decrease both of unit productivity and extraction efficiency because lower temperature degrees were unable to carry out the extraction process. Relating to the effect of air pressures, the obtained results show that increasing air pressure from 0.5 to $1.5 \mathrm{~kg} / \mathrm{cm}^{2}$, measured at different dilution percentages of 1:5, 1:10, 1:15 and 1:20, increased unit productivity from 1.39 to 1.62 , from 1.43 to 1.64 , from 1.31 to 1.53 and from 1.29 to $1.49 \mathrm{l} / \mathrm{h}$, also increased extraction efficiency from 78.66 to 91.56 , from 83.25 to 95.33 , from 77.00 to 90.21 and from 76.11 to $88.10 \%$, respectively. Further increase in air pressure more than 1.5 up to $2.0 \mathrm{~kg} / \mathrm{cm}^{2}$ measured at the same dilution percentages decreased unit productivity from 1.62 to 1.55 , from 1.64 to 1.59 , from 1.53 to 1.48 and from 1.49 to $1.44 \mathrm{l} / \mathrm{h}$, also decreased extraction efficiency from 91.56 to 87.79 , from 95.33 to 92.85 , from 


\section{Unit productivity}

\section{Extraction efficiency}
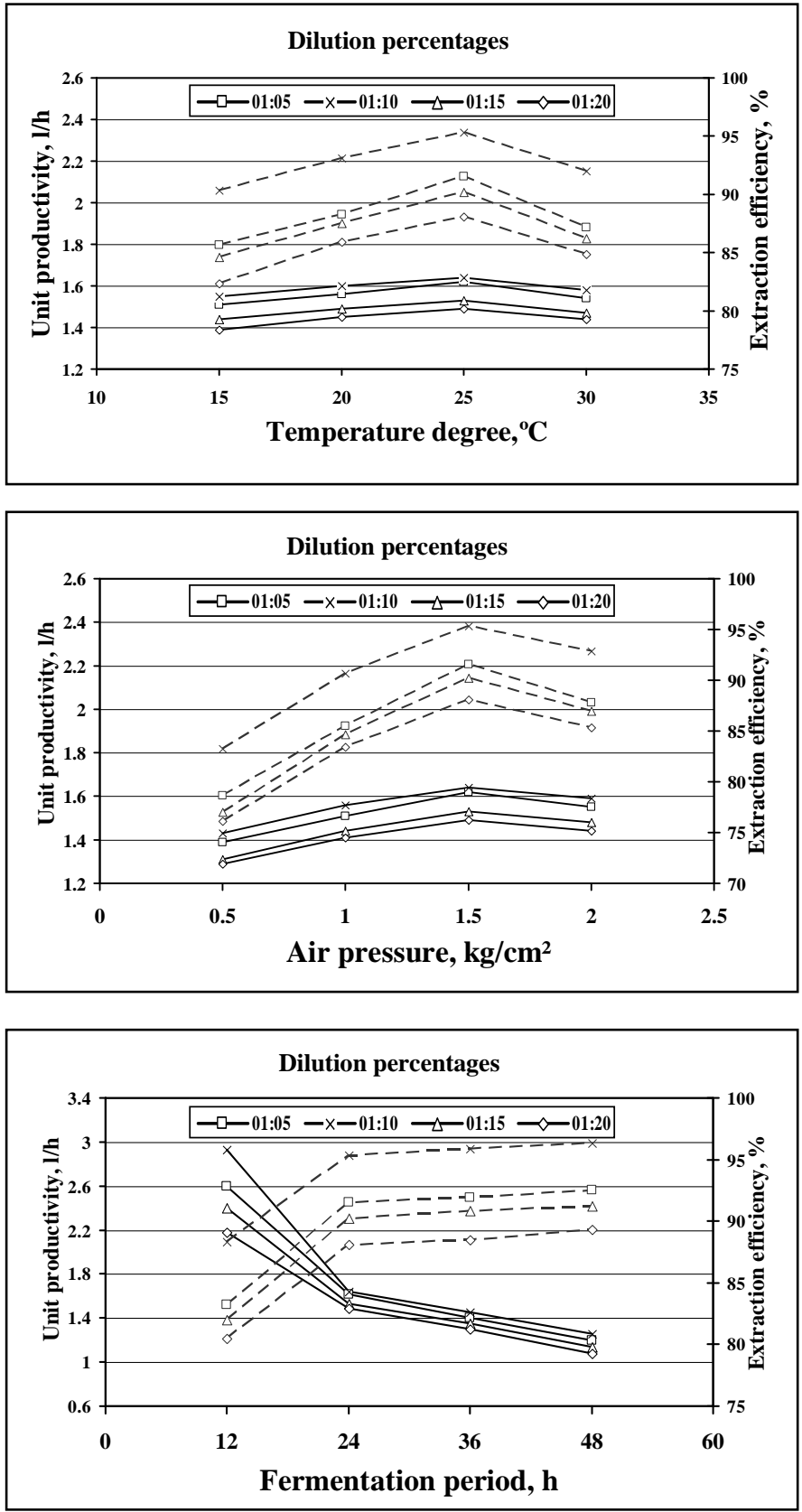

Fig. (2): Effect of temperature degree, air pressure and fermentation period on unit productivity and extraction efficiency at different dilution percentages. 
90.21 to 86.95 and from 88.10 to $85.34 \%$, respectively at constant temperature degree of $25^{\circ} \mathrm{C}$ and fermentation period of $24 \mathrm{~h}$. Higher values of air pressures more than the optimum value tend to decrease both of unit productivity and extraction efficiency because of the too rapid or forceful mixing that can physically destroy beneficial microorganism populations in the tea, added to the increase in the amount of compost loss which delivered with air. Lower values of air pressures less then the optimum value tend to decrease both of unit productivity and extraction efficiency because mixing that is too slow may not be sufficient to extract enough organisms from the compost. In addition insufficiently vigorous or slow mixing can allow the development of bio-films and anaerobic conditions, hence to decrease producing compost extraction. As to the effect of fermentation periods, results show that increasing fermentation period from 12 to $48 \mathrm{~h}$, measured at different dilution percentages of 1:5, $1: 10,1: 15$ and $1: 20$, decreased unit productivity from 2.60 to 1.20 , from 2.93 to 1.26 , from 2.40 to 1.14 and from 2.18 to $1.08 \mathrm{l} / \mathrm{h}$, while increased extraction efficiency from 83.25 to 92.50 , from 88.33 to 96.34 , from 82.00 to 91.25 and from 80.50 to $89.36 \%$, respectively at constant temperature degree of $25^{\circ} \mathrm{C}$ and air pressure of $1.5 \mathrm{~kg} / \mathrm{cm}^{2}$. Higher values of fermentation periods more than the optimum value tend to decrease unit productivity because with high periods, oxygen becomes limited, microbial populations will increase under anaerobic conditions. Brief anaerobic periods for few minutes, may not be undesirable, if the aerobic organisms are not destroyed or become inactive. However elongated anaerobic conditions may make many beneficial microorganisms inactive or kill them, accordingly decrease producing compost extraction. As a result a long brewing time does not always produce good quality compost tea. Lower values of fermentation periods less than the optimum value tend to decrease extraction efficiency because brewing time becomes limited and not sufficient for producing compost tea.

\subsection{Influence of some operating parameters on power and energy requirements at different dilution percentages:}

Power and energy requirements are more sensitive to different factors such as dilution percentage, temperature degree, air pressure and fermentation period. Representative values of both required power and specific energy versus temperature degree at different dilution percentages are given in Fig.3. Results show that increasing temperature degree from 15 to $30^{\circ} \mathrm{C}$, measured at different dilution percentages of 1:5, 1:10, 1:15 and 1:20, decreased required power from 0.59 to 0.43 , from 0.55 to 0.38 , from 0.43 to 0.30 and from 0.38 to $0.26 \mathrm{~kW}$, 

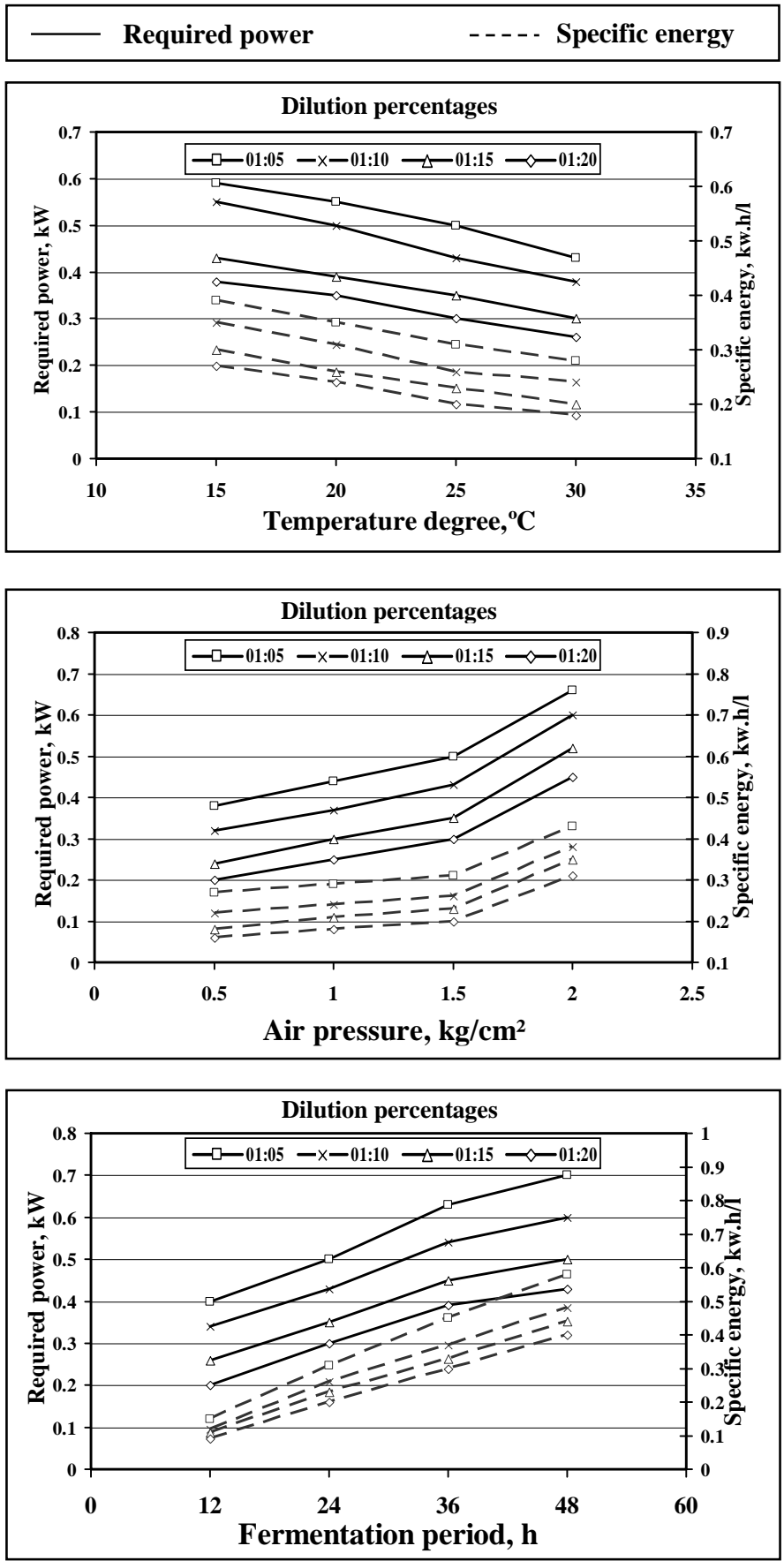

Fig. (3): Effect of temperature degree, air pressure and fermentation period on power and energy requirements at different dilution percentages. 
also decreased specific energy from 0.39 to 0.28 , from 0.35 to 0.24 , from 0.30 to 0.20 and from 0.27 to $0.18 \mathrm{kw} . \mathrm{h} / \mathrm{l}$, respectively at constant air pressure of $1.5 \mathrm{~kg} / \mathrm{cm}^{2}$ and fermentation period of $24 \mathrm{~h}$. Required power as well as specific energy decreased by increasing temperature degree due to the facility in extraction process and also the decrease of power required for operating the compressor. Required power, as well as energy requirements is too related to air pressure Fig. 3. Results show that increasing air pressure from 0.5 to $2.0 \mathrm{~kg} / \mathrm{cm}^{2}$, measured at different dilution percentages of $1: 5$, $1: 10,1: 15$ and $1: 20$, increased required power from 0.38 to 0.66 , from 0.32 to 0.60 , from 0.24 to 0.52 and from 0.20 to $0.45 \mathrm{~kW}$, also increased specific energy from 0.27 to 0.43 , from 0.22 to 0.38 , from 0.18 to 0.35 and from 0.16 to $0.31 \mathrm{kw} . \mathrm{h} / \mathrm{l}$, respectively at constant temperature degree of $25^{\circ} \mathrm{C}$ and fermentation period of $24 \mathrm{~h}$. Required power as well as specific energy increased by increasing air pressure because of the increase of consumption ampere required for operating the compressor which is responsible to increase air pressure. Fermentation period is considered an important factor which affects on power and energy requirements Fig. 3. The obtained results show that increasing fermentation period from 12 to $48 \mathrm{~h}$, measured at different dilution percentages of 1:5, 1:10, 1:15 and 1:20, increased required power from 0.40 to 0.70 , from 0.34 to 0.60 , from 0.26 to 0.50 and from 0.20 to $0.43 \mathrm{~kW}$, also increased specific energy from 0.15 to 0.58 , from 0.12 to 0.48 , from 0.11 to 0.44 and from 0.09 to $0.40 \mathrm{kw} . \mathrm{h} / \mathrm{l}$, respectively at constant temperature degree of $25^{\circ} \mathrm{C}$ and air pressure of $1.5 \mathrm{~kg} / \mathrm{cm}^{2}$. Required power as well as specific energy, increased by increasing fermentation period because of the increase of brewing time resulted in the increase of compressor working time that tend to consume more power.

\subsection{Influence of some operating parameters on hourly and operational costs at different dilution percentages:}

A complete cost analysis was made at different operating conditions and related with unit productivity. The resulting operating cost was found to be affected significantly by dilution percentage, temperature degree, air pressure and fermentation period. To be more accurate, the operational cost was used as an important indicator for selecting optimum dilution percentage suited for a certain temperature degree, certain air pressure and a certain fermentation period. The operational cost was based on unit productivity, power and hourly cost. Therefore, minimization of operational cost in relation to both temperature degrees, air pressure and fermentation period is required to perform the aeration and extraction operations as good 
as possible. Representative values of both hourly and operational costs versus temperature degree at different dilution percentages are given in Fig.4. Results show that increasing temperature degree from 15 to $30^{\circ} \mathrm{C}$, measured at different dilution percentages of 1:5, 1:10, 1:15 and 1:20, decreased hourly cost from 3.84 to 3.76 , from 3.82 to 3.73 , from 3.76 to 3.69 and from 3.73 to 3.67 L.E./h, respectively. On the other hand results show that increasing temperature degree from 15 to $25^{\circ} \mathrm{C}$, measured at different dilution percentages of 1:5, 1:10, 1:15 and 1:20, decreased operational cost from 2.54 to 2.34 , from 2.46 to 2.29 , from 2.61 to 2.43 and from 2.68 to 2.48 L.E./l. Any further increase in temperature degree more than 25 up to $30^{\circ} \mathrm{C}$ measured at the same dilution percentages increased operational cost from 2.34 to 2.44 , from 2.29 to 2.36 , from 2.43 to 2.51 and from 2.48 to $2.55 \mathrm{l} / \mathrm{h}$, respectively at constant air pressure of $1.5 \mathrm{~kg} / \mathrm{cm}^{2}$ and fermentation period of $24 \mathrm{~h}$. Both higher and lower values of temperature degree more or less than the optimum value tend to increase operational cost due to the decrease in unit productivity. Considering air pressure, results show that increasing air pressure from 0.5 to $2.0 \mathrm{~kg} / \mathrm{cm}^{2}$, measured at different dilution percentages of 1:5, 1:10, 1:15 and 1:20, increased hourly cost from 3.73 to 3.87 , from 3.70 to 3.84 , from 3.66 to 3.80 and from 3.64 to 3.77 L.E./h. While results show that increasing air pressure from 0.5 to 1.5 $\mathrm{kg} / \mathrm{cm}^{2}$, measured at different dilution percentages of 1:5, 1:10, 1:15 and 1:20, decreased operational cost from 2.68 to 2.34 , from 2.58 to 2.29 , from 2.79 to 2.43 and from 2.82 to 2.48 L.E./l. Any further increase in air pressure more than 1.5 up to $2.0 \mathrm{~kg} / \mathrm{cm}^{2}$, measured at the same dilution percentages increased operational cost from 2.34 to 2.50 , from 2.29 to 2.42, from 2.43 to 2.57 and from 2.48 to $2.62 \mathrm{l} / \mathrm{h}$, respectively at constant temperature degree of $25^{\circ} \mathrm{C}$ and fermentation period of $24 \mathrm{~h}$. Both higher and lower values of temperature degree more or less than the optimum value tend to increase operational cost due to the decrease in unit productivity. As to fermentation period, obtained results show that increasing fermentation period from 12 to $48 \mathrm{~h}$, measured at different dilution percentages of 1:5, $1: 10,1: 15$ and $1: 20$, increased hourly cost from 3.74 to 3.89 , from 3.71 to 3.84, from 3.68 to 3.79 and from 3.65 to 3.76 L.E./h, also increased operational cost from 1.45 to 3.24 , from 1.27 to 3.05 , from 1.53 to 3.32 and from 1.67 to 3.48 L.E./l, respectively at constant temperature degree of $25^{\circ}$ $\mathrm{C}$ and air pressure of $1.5 \mathrm{~kg} / \mathrm{cm}^{2}$. Operational cost increased by increasing fermentation period due to the increase of brewing time resulting in increase of required power. 

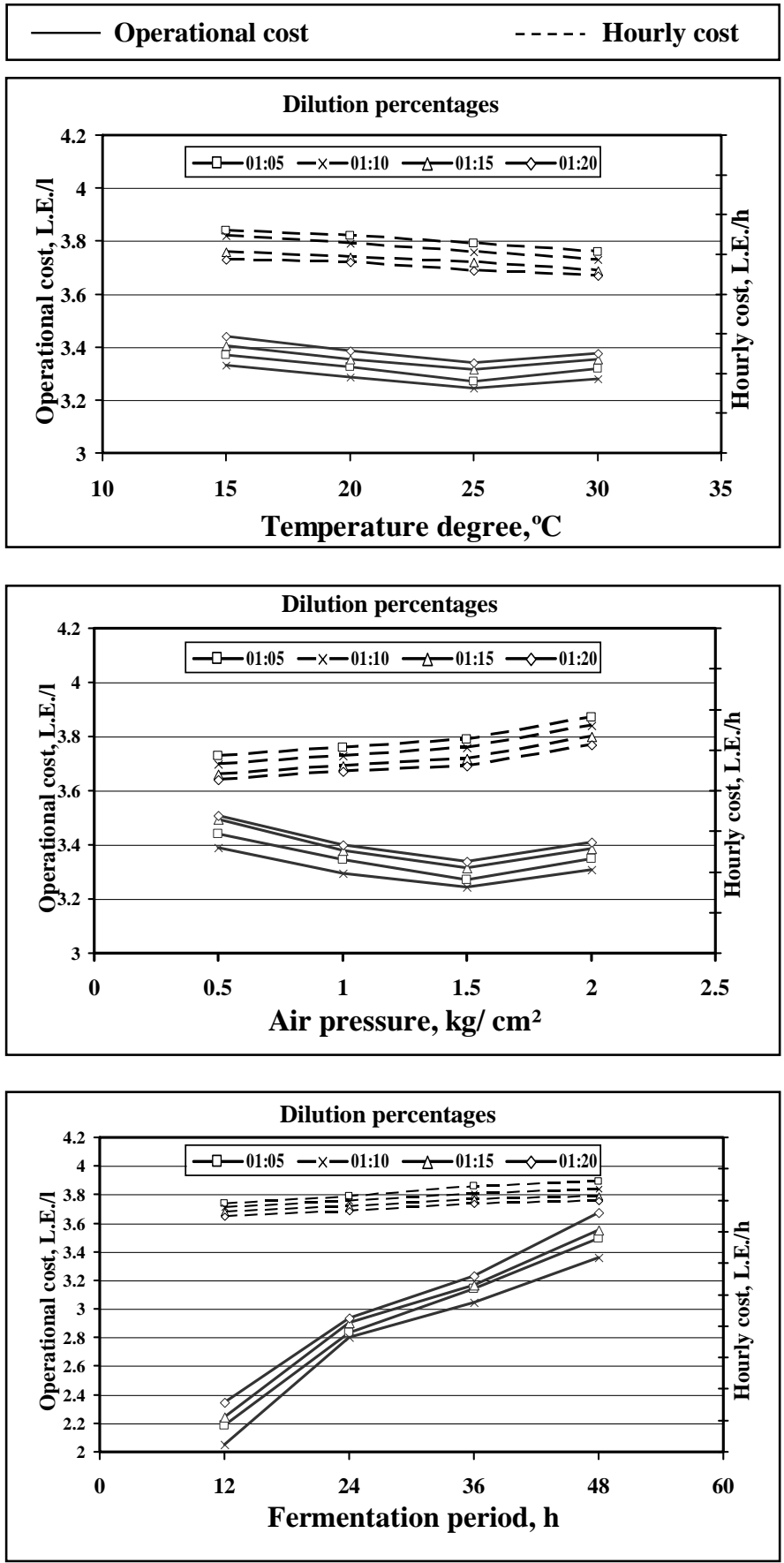

Fig. (4): Effect of temperature degree, air pressure and fermentation period on hourly and operational costs at different dilution percentages. 


\section{CONCLUSION}

The experimental results recommended the following:

- Operate the aerobic digester at air pressure of $1.5 \mathrm{~kg} / \mathrm{cm}^{2}$.

- Adjust the dilution percentage of 10 parts water with one part compost.

- Operate the manufactured unit at a temperature degree of about $25^{\circ} \mathrm{C}$.

- Adjust the aerobic digester at fermentation period of $24 \mathrm{~h}$.

\section{REFERRENCES}

Awady, M. N. (1978): Tractor and farm machinery. Text book, Faculty of Agriculture, Ain-Shams University. Pp: 164-167.

Awady, M. N; E. Y. Ghoniem, and A. I. Hashish (1982): Agriculture comparison between wheat combine harvesters under Egyptian conditions. Res. Bul. Ain-Shams Univ.:13p.

Carballo, T. M; V. Gil, L. F. Calvo and A. Moran (2009): The influence of aeration system, temperature and compost origin on the phytotoxicity of compost tea. Compost Science \& Utilization, 17 (2): 127-139.

Carballo, T. M; V. Gil, X. Gomez, F. Gonzalez-Andres, A. Moran (2008): Characterization of different compost extracts using Fouriertransform infrared spectroscopy (FTIR) and thermal analysis. Biodegradation, 19(6) 815-830.

Ingham E. (2003) compost Tea Promises \& Practicalities. A voice for EcoAgriculture (ACRES) USA, December Vol. 33, No. 12.

Ingham, E. (2005): The compost tea brewing manual. US Printings, Soil Foodweb Incorporated, Oregon.

Palmer, A. K; K. J. Evans and D. A. Metcalf (2010): Characters of aerated compost tea from immature compost that limit colonization of bean leaflets. Journal of Applied Microbiology, 109 (5): 16191631.

Scheuerell, S. (2003): Understanding how compost tea can control disease. BioCycle 44 (2) 20-25. 
Scheuerell, S. J; W. F. Mahaffee (2004): Compost tea as a container medium drench for suppressing seedling damping-off caused by "Pythium ultimum" Phytopathology, 94 (11): 1156-1163.

Scheuerell, S. J; W. F. Mahaffee (2006): Variability associated with suppression of gray mold on geranium by foliar applications of nonaerated and aerated compost teas. Plant Disease, 90 (9): 12011208.

\section{الملخص العربـى}

\section{تصنيع وتقييم أداء وحدة محلية الصنع لإتتاج مستخلص الكمبوست}

\section{د. محمد محمد بلرز}

تمثل المخلفات الزر اعبة مشكلة حرجة لدى المزارع المصري بعد انتهاء موسم الحصاد، ونظر اً لعدم

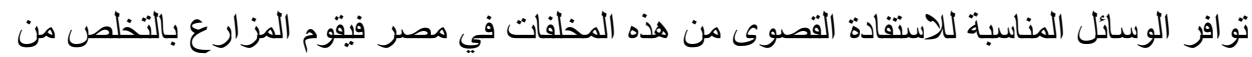

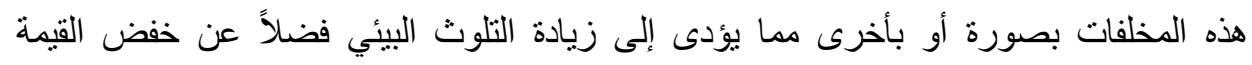

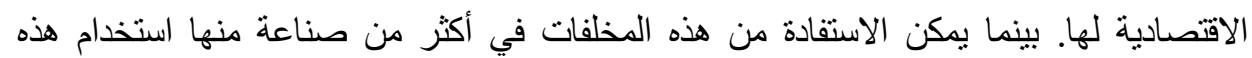
المخلفات في إعداد السماد العضوي (الكمبوست)، ولكن وجد أنه يمكن تعظيم الاستفادة من هذا المنت العنتج

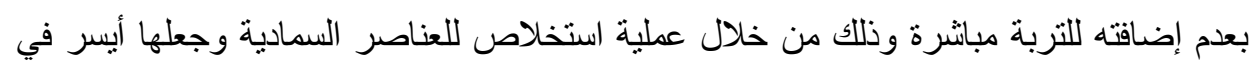

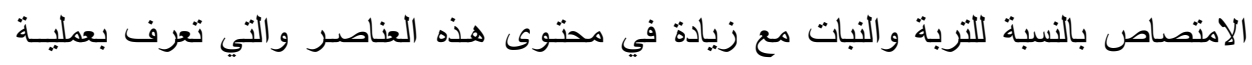

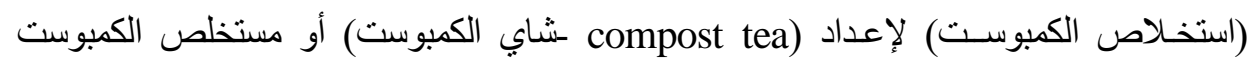
كعملية منفصلة.

وفو ائد هذا المستخلص بالنسبة للتربة كثيرة تتمثل في تحسين بناء التربة مع زيادة العناصر الغذائية

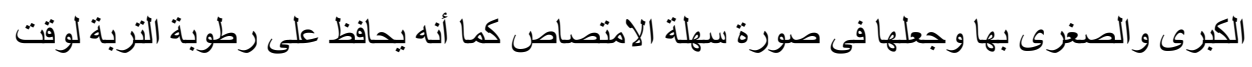

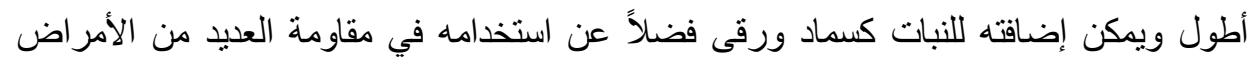

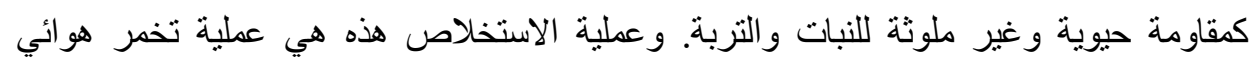

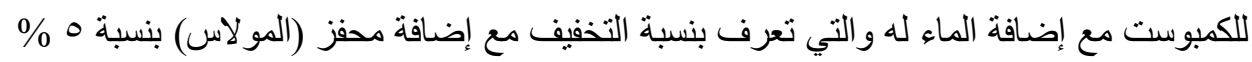

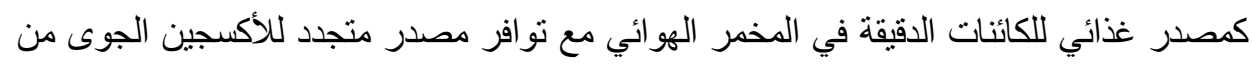

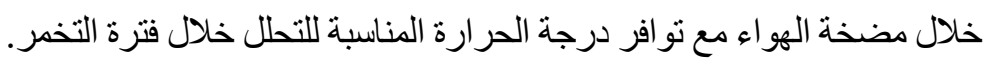

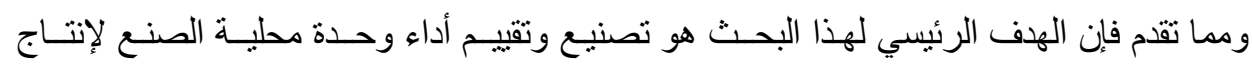

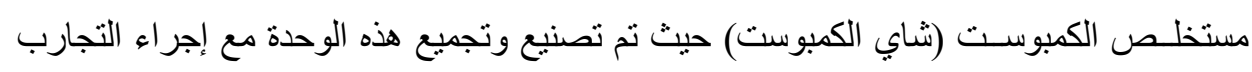

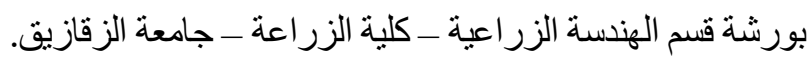

*مدرس - قسم الهندة الزراعية ـ كلية الزراعة - جامعة الزقازيق - مصر. 


\section{وفيما يلى الأهداف الخاصة بهذا البحث:}

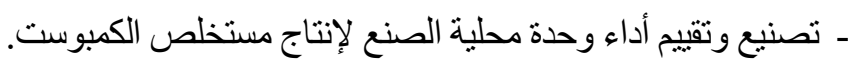

ـ تحديد القيم التشغيلية المثلى لكل من درجة الحرارة ومعدل تدفق الهو اء وفترة التخمر ونسبة

$$
\text { التخفيف و التي تؤثر على أداء الوحدة. }
$$

ـ تقييم الوحدة المصنعة من الناحية الاقتصادية.

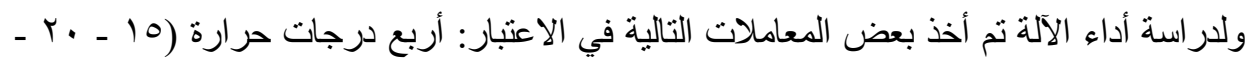

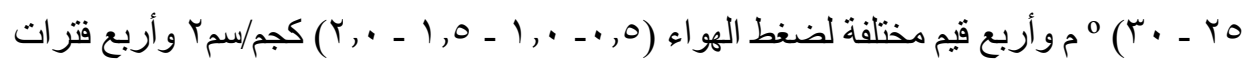

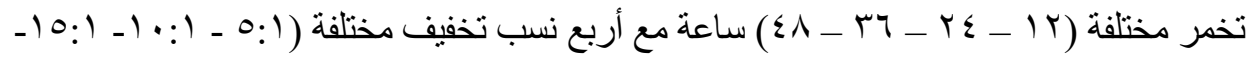

ولتقييم أداء الوحدة تم أخذ القياسات التالية: معدل الإنتاجية ـ كفاءة الاستخلاص ـ القدرة المستهلكة وكذا الطاقة مع حساب تكاليف النتخيل. وقد أظهرت النتائج أن أفضل القيم المتحصل عليها أثناء التشغيل بالنسبة: لكفاءة الاستخلاص سب, 90 \% ، و ومعدل إنتاجية ء 7, 1 لتر/ساعة, وكانت الطاقة

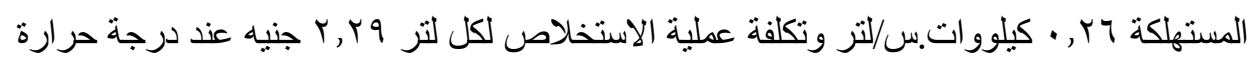

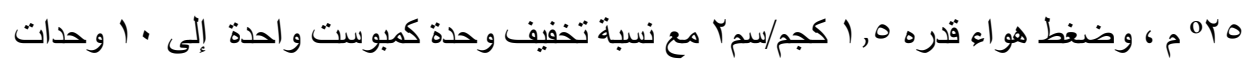

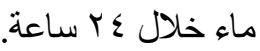

$$
\text { لأ توصى الدراسة بما يلي: }
$$

ـ تشغيل مضخة الهو اء على ضغط هو اء قدره 0 , 1 كجم/سمب أثناء عملية الاستخلاص. - استخدام نسبة تخفيف وحدة كمبوست واحدة إلى • ا وحدات ماء خلال ع ساعة. - تشغيل الوحدة المصنعة على درجة حرارة هبه م خلال فترة التخمر. ـ تشغيل الوحدة المصنعة لفترة تخمر مقدار ها ع ب ساعة. 